\title{
2014-2016 Yılları Arasında Periodontoloji Kliniğine Başvuran Hastaların Periodontal Durum, Sistemik Hastalık ve Kişisel Alışkanlıklarının Değerlendirilmesi
}

\author{
Bilge Meracı Yıldıran(0000-0001-9848-0927) ${ }^{\alpha}$, Şadiye Günpınar(0000-0001-6100-322X) ${ }^{\beta}$
}

Selcuk Dent J, 2021; 8: 635-643 (Doi: 10.15311/selcukdentj.741243)

Bașvuru Tarihi: 22 Mayıs 2020 Yayına Kabul Tarihi: 04 Ocak 2021

\section{öz}

2014-2016 Yılları Arasında Periodontoloji Kliniğine Başvuran Hastaların Periodontal Durum, Sistemik Hastalık ve Kişisel Alışkanlıklarının Değerlendirilmesi

Amaç: Bu kesitsel retrospektif çalışmanın amacı, Bolu Abant izzet Baysal Üniversitesi Diş Hekimliği Fakültesi Periodontoloji Anabilim Dalı öğrenci kliniğinde başlangıç periodontal tedavileri yapılan 1800 hastanın sistemik hastalık, periodontal durum ve kişisel alışkanlıklarının değerlendirilmesidir.

Gereç ve Yöntemler: Çalışmaya dahil edilen bireylerin hasta formlarına kaydedilmiş olan demografik, dental şikayet ve sistemik durum bilgileri, sigara kullanımı, bruksizm ve ağız solunumu varlığı ile periodontal klinik parametreleri değerlendirildi. Bireyler periodontal durumlarına göre gingivitis (G), kronik periodontitis (KP) ve agresif periodontitis (AgP) olmak üzere üç gruba ayrıldı. Oluşturulan gruplar periodontal klinik parametreler (plak indeksi, gingival indeks, sondalamada kanama), sistemik hastalık (tip 2 diyabet, hipertansiyon ve kardiyovasküler hastalıklar gibi) ve kişisel alışkanlıklar açısından karşılaştıııldı. Verilerin istatistiksel analizleri SPSS 23.0 paket programı kullanılarak yapıldı.

Bulgular: Çalışma popülasyonunun (\%59.5'i kadın ve \%40.5'i erkek) yaş ortalamasının $29.48 \pm 11.75$ olduğu belirlendi. Hastaların \%70.8'ine G, \%28.7'sine KP ve \%0.5'ine ise AgP teşhisi konulduğu saptandı. Erkek hastalarda sigara kullanımı prevalansının kadın hastalardan daha yüksek olduğu görüldü $(p<0.001)$. Tip 2 diyabet, hipertansiyon ve kardiyovasküler hastalıklar bakımından cinsiyetler arasında anlamlı bir fark görülmezken $(p>0.05)$; tiroid hastalıkları ve alerji durumunun kadınlarda erkeklere göre daha yüksek oranda olduğu tespit edildi $(p<0.001)$. Sigara kullanımı, diyabet, hipertansiyon, kardiyovasküler hastalık $(p<0.001)$ ve tiroid hastalıkları $(p<0.05)$ prevalansının KP grubunda artış gösterdiği belirlendi. Çok kategorili (multinominal) lojistik regresyon analizi sonucunda yaş, sigara kullanımı, sistemik hastalık varlığı ve hipertansiyon değişkenlerinin periodontitis gelişme olasılığını arttırdığı saptandı.

Sonuç: Bu çalışmanın sınırları dahilinde, sistemik durum ve kişisel alışkanlıkların periodontal hastalık gelişiminde önemli bir rol oynayabileceği söylenebilir.

\section{ANAHTAR KELIMELER}

Epidemiyoloji, Periodontal hastalıklar, Sigara, Sistemik hastalıklar

Periodontal hastalıklar, dünya nüfusunun büyük çoğunluğunun muzdarip olduğu kronik hastalıkların önemli bir bölümünü oluşturur. ${ }^{1}$ En sık görülen periodontal hastalıklar dental plağa bağlı gelişen gingivitis ve periodontitistir. Gingivitis, dişeti kenarında biriken mikrobiyal dental plağa karşı gelişen lokal

\section{ABSTRACT}

Evaluation of Periodontal Status, Systemic Diseases and Individual Habits of Patients in Periodontology Clinic Between Years 2014-2016

Background: This retrospective cross-sectional study aimed to evaluate the frequency of systemic disease, periodontal status and individual habits of 1800 patients, who underwent initial periodontal treatments in the student clinic of Bolu Abant Izzet Baysal University, Faculty of Dentistry, Department of Periodontology.

Methods: The demographic characteristics, complaints, systemic status, smoking, bruxism, mouth breathing and periodontal clinical parameters, which were previously recorded in the patient forms, were evaluated in this study. Patients were diagnosed as gingivitis (G), chronic periodontitis (CP) and aggressive periodontitis (AgP). Clinical parameters (plaque index, gingival index and bleeding on probing), presence of systemic disease (such as diabetes mellitus, hypertension and cardiovascular diseases) and individual habits were compared between the groups. Statistical analyses were performed via SPSS 23.0 program.

Results: The average age with its standard deviation of the study population ( $59.5 \%$ female, $40.5 \%$ male) was $29.48 \pm 11.75$. It was determined that $70.8 \%, 28.7 \%$ and $0.5 \%$ of the patients were $\mathrm{G}$, $\mathrm{CP}$ and $\mathrm{AgP}$, respectively. The prevalence of smoking was higher in males $(p<0.001)$ than females. Diabetes mellitus, hypertension and cardiovascular disease frequencies did not differ along gender $(p>0.05)$, while the frequency of thyroid diseases and allergy were higher in females than males $(p<0.001)$. The CP patients had increased prevalence of smoking, diabetes mellitus, hypertension, cardiovascular $(p<0.001)$ and thyroid diseases $(p<0.05)$. The results of multinominal logistic regression analysis demonstrated that variables such as age, smoking, presence of systemic disease and hypertension increased the probability of developing periodontitis.

Conclusion: Within the limit of this study, it may be concluded that systemic conditions and individual habits may have essential role in periodontal condition.

\section{KEYWORDS}

Epidemiology, Periodontal diseases, smoking, Systemic diseases

inflamatuar yanıtın neden olduğu dişeti enflamasyonudur. Dental plağın uzaklaştırıması ile birlikte kendiliğinden iyileşir. ${ }^{2}$ Etkenin uzaklaştırılmadığı ve enflamasyonun kontrol altına alınamadığı durumlarda periodonsiyumu oluşturan destek dokularda yıkımın eşlik ettiği periodontitis

\footnotetext{
${ }^{\alpha}$ Karabük Üniversitesi Diş Hekimliği Fakültesi Periodontoloji AD. Karabük, Türkiye

$\beta$ Bolu Abant İzzet Baysal Üniversitesi Diş Hekimliği Fakültesi Periodontoloji AD. Bolu, Türkiye
} 
tablosu oluşur. Dişi destekleyen dokulardaki ileri yıkım dişlerde mobiliteye ve devamında dis, kayıplarına neden olur. ${ }^{3}$

Periodontal hastalıklar 'eko-genetik hastalıklardır' ve bazı genetik veya çevresel risk faktörleri (interlökin-1 gen polimorfizmi, sigara kullanımı, diyabet ve kronik/hiper enflamasyon varlığı gibi) bireyleri periodontal hastalıklara karşı daha duyarlı hale getirir. ${ }^{4}$ Sistemik hastalık varlığında konağın doku cevabında meydana gelen değişimler bireyin periodontal hastalık gelişimine yatkınlığının artmasına ve mevcut periodontal hastalığın şiddetlenmesine neden olabilir. Diğer yandan periodontal enflamasyon varlığı, dental plaktaki patojen bakterilerin akciğer ve bağırsak gibi diğer mukozal yüzeylere transferi ve bütünlüğü bozulmuş oral dokulardan kan dolaşımına girip uzak bölgeleri enfekte etmesi veya bu bölgelerde proinflamatuar sitokinlerin ve/veya akut faz proteinlerinin salınımını uyarması yoluyla kronik sistemik hastalıkların oluşumunu ve prognozunu etkileyebilir. ${ }^{5}$ Son yıllarda birçok çalışmada periodontal hastalık ile bazı sistemik hastalık ve durumlar arasındaki ilişki araştırılmıştır. Bunlara kardiyovasküler hastalıklar, hipertansiyon, tip 2 diyabet, solunum sistemi hastalıkları, endokrin bozuklukları, alerji, osteoporoz gibi hastalıklar ve gebelikte karşılaşılan istenmeyen durumlar örnek olarak verilebilir. .-9 $^{6-9}$

Ülkemizde diş hekimliği fakültelerine başvuran hastaların periodontal durumları ve sistemik hastalıkları konusunda sınırlı sayıda çalışma yapılmıştır. ${ }^{10-13} \mathrm{Bu}$ kesitsel retrospektif çalışmanın amacı, Bolu Abant İzzet Baysal Üniversitesi Diş Hekimliği Fakültesi Periodontoloji Anabilim Dalı ögrenci kliniğinde bașlangıc, periodontal tedavileri yapılan 1800 hastanın sistemik hastalık, periodontal durum ve kişisel alışkanlıklarının değerlendirilmesidir.

\section{GEREÇ VE YÖNTEMLER}

Bu retrospektif çalışmaya Ocak 2014-Aralık 2016 tarihleri arasında Bolu Abant İzzet Baysal Üniversitesi Üniversitesi Diş Hekimliği Fakültesi Periodontoloji Anabilim Dalına başvurmuş ve öğrenci kliniğinde muayene edilmiş bireylere ait rastgele seçilmiş 1800 hasta formu dahil edildi. Çalışma protokolü, Bolu Abant İzzet Baysal Üniversitesi Klinik Araştırmalar ve Etik Kurulu tarafından onaylandı (Karar No: 2019/164, Tarih: 16.07.2019).

$\mathrm{Bu}$ çalışma için periodontal hastalıklı bireylere ait eksiksiz olarak doldurulmuş hasta formlarındaki demografik veriler (cinsiyet ve yaş), hastanın kliniğe geliş sebebi (diş eti kanaması, diş eti çekilmesi, diştaşı temizliği, abse/ağrı, ağız kokusu, dişlerde sallanma, diş hassasiyeti, renklenmeler, genel kontrol, diğer kliniklerden yönlendirilme vb.), sistemik hastalık ve/veya durumlar (tip 2 diyabet, hipertansiyon, kardiyovasküler hastalıklar, tiroid hastalıkları, gastrointestinal hastalıklar, solunum hastalıkları, kan hastalıkları, böbrek hastalıkları, karaciğer hastalıkları, kanser, alerji, hamilelik/emzirme vb.) ile kişisel alışkanlıkları (sigara, bruksizm ve ağız solunumu) incelendi. Periodontal değerlendirme için hasta formlarında kayıtlı olan tedavi öncesi periodontal klinik ölçümler incelendi. $\mathrm{Pi}^{14}, \mathrm{Gi}^{15}$ ve sondlamada kanama kayıtları maksiller ve mandibular birinci molarlar ve kaninkanin arası kesici dişler olmak üzere toplam 16 dişten ve her bir dişin 6 yüzeyinden (meziyobukkal, midbukkal, distobukkal, meziyolingual, midlingual ve distolingual) yapıldı. Her bireye ait ortalama Pi (PI $\left.{ }_{\text {ort }}\right)$ ve ortalama $\mathrm{GI}$ ( $\left.\mathrm{Gi}_{\text {ort}}\right)$ değerleri, her bir diş yüzeyine ait Pi ve Gi skorlarının toplamının, değerlendirilen toplam diş yüzeyi sayısına bölünmesi ile hesaplandı. Sondlamada kanama yüzdeleri $\left(\mathrm{SK}_{\%}\right)$ ise sondlamada kanama görülen toplam yüzey sayısının değerlendirilen toplam diş yüzey sayısına bölünmesi ile belirlendi. Çalışmaya dahil edilen bireyler, klinik muayeneleri sırasında danışman öğretim üyesi (Ş.G.) gözetiminde 1999 yılında geliştirilen sınıflama doğrultusunda belirlendi ve hasta formlarına kaydedildi. Buna göre bireyler periodontal durum teşhislerine göre gingivitis $(\mathrm{G})$, kronik periodontitis $(\mathrm{KP})$ ve agresif periodontitis $(\mathrm{AgP})$ olmak üzere 3 gruba ayrıldı. ${ }^{16}$

\section{İstatistiksel Analiz}

Çalışma sonucunda elde edilen verilerin istatistiksel analizi istatistik paket programı kullanılarak (SPSS v.23.0; IBM, Chicago, IL, USA) gerçekleștirildi. Verilerin normal dağılım gösterip göstermediğ Shapiro-Wilk normallik testi ile degerlendirildi. Niteliksel verilerin gruplar arası karşlaştırması için Pearson Ki-Kare testi, niceliksel verilerin çoklu karşılaștırması için ise Kruskal Wallis testi ve Mann Whitney U testi kullanıldı. Periodontitis ile ilişkili faktörlerin belirlenmesinde her bağımsız değişken için tek değişkenli lojistik regresyon analizi yapıldı. P değeri $<0.05$ olan faktörler, çok değişkenli lojistik regresyon analizi ile değerlendirildi. Çoklu doğrusallığın önlenmesi için parametrik olmayan verilerde Spearman korelasyon testi kullanıldı. Sonuçarın istatistiksel anlamlılığ $p<0.05$ düzeyinde değerlendirildi.

\section{BULGULAR}

Hastaların kliniğe geliş şikayetleri değerlendirildiğinde, bireylerin büyük çoğunluğunun diğer diş hekimleri, diş hastaneleri veya fakültedeki diğer bölümler tarafından periodontoloji kliniğine yönlendirilme ile başvurduğu belirlendi ( $n=951)$. En sık bildirilen diğer şikayetler ise sırasıyla diştaşı temizliği $(n=279)$, genel kontrol $(n=140)$, ağrı/abse varlığı $(n=121)$ ve diş eti kanamasıydı $(n=106)$.

Çalışma popülasyonuna ait demografik bulgular ile klinik periodontal parametrelerin cinsiyete göre karşılaştırılması Tablo 1'de, bireylerin periodontal teşhis, sigara kullanımı ve sistemik hastalık verilerinin cinsiyete göre karşılaştırılması ise Tablo 2'de verildi. Çalışmada kadın bireylerin çoğunlukta olduğu (\% 59.5) saptandı. Erkek bireylerin yaş ortalamasının kadın bireylerden istatistiksel olarak anlamlı düzeyde daha yüksek olduğu tespit edildi $(p<0.001)$. Periodontal klinik ölçümler açısından 
karşılaştırma yapıldığında Pi̇ort, Giort ve SK\% değerlerinin erkeklerde istatistiksel olarak anlamlı derecede daha yüksek olduğu saptandı.

Tablo 1.

Çalışma popülasyonuna ait demografik verilerin ve klinik periodontal ölçümlerin cinsiyete göre karşılaştırılması

\begin{tabular}{|c|c|c|c|c|c|}
\hline & & Toplam & Kadın & Erkek & $\mathbf{P}^{*}$ \\
\hline \multicolumn{2}{|c|}{$\begin{array}{c}\text { Çalışma popülasyonu } \\
\mathrm{n}(\%)\end{array}$} & $1800(100)$ & $1071(59.50)$ & $729(40.50)$ & \\
\hline \multirow{2}{*}{ Yaş } & ort $\pm s s$ & $29.48 \pm 11.76$ & $28.61 \pm 11.20$ & $30.76 \pm 12.43$ & \multirow{2}{*}{0.000} \\
\hline & $\begin{array}{l}\text { ortanca } \\
\text { (min-maks) }\end{array}$ & $25.00(12.00-76.00)$ & $24.00(12.00-73.00)$ & $27.00(15.00-76.00)$ & \\
\hline \multirow{2}{*}{$\mathrm{Pi}$} & ort \pm ss & $1.36 \pm 0.51$ & $1.28 \pm 0.47$ & $1.47 \pm 0.55$ & \multirow{2}{*}{0.000} \\
\hline & $\begin{array}{l}\text { ortanca } \\
\text { (min-maks) }\end{array}$ & $1.19(0.00-3.00)$ & $1.13(0.00-3.00)$ & $1.33(0.00-3.00)$ & \\
\hline \multirow{2}{*}{ Gi } & ort $\pm s s$ & $1.41 \pm 0.51$ & $1.37 \pm 0.50$ & $1.47 \pm 0.52$ & \multirow{2}{*}{0.000} \\
\hline & $\begin{array}{l}\text { ortanca } \\
\text { (min-maks) }\end{array}$ & $1.31(0.00-3.00)$ & $1.23(0.00-3.00)$ & $1.38(0.00-3.00)$ & \\
\hline \multirow{2}{*}{$\mathrm{SK}_{\approx}$} & ort $\pm s s$ & $47.75 \pm 40.29$ & $45.54 \pm 40.18$ & $50.98 \pm 40.25$ & \multirow{2}{*}{0.005} \\
\hline & $\begin{array}{l}\text { ortanca } \\
\text { (min-maks) }\end{array}$ & $43.75(0.00-100.00)$ & $37.50(0.00-100.00)$ & $50.00(0.00-100.00)$ & \\
\hline
\end{tabular}

Mann Whitney $U$ test, $p<0.05$

n: birey sayısı, ort \pm ss: aritmetik ortalama \pm standart sapma, min: minimum, maks: maksimum, Pi: plak indeksi, Gi: gingival indeks, SK: sondlamada kanama.

Tablo 2.

Çalışma popülasyonuna ait periodontal teşhis, sigara kullanımı ve sistemik hastalık verilerinin cinsiyete göre karşılaştırılması

\begin{tabular}{|c|c|c|c|c|}
\hline & Toplam & Kadın & Erkek & \\
\hline & $n(\%)$ & $n(\%)$ & $\mathrm{n}(\%)$ & \\
\hline Gingivitis & $1275(70.83)$ & $812(75.82)$ & $463(63.51)$ & 0.00 \\
\hline Kronik periodontitis & $516(28.67)$ & 255 (23.81) & $261(35.80)$ & 0.000 \\
\hline Agresif periodontitis & $9(0.50)$ & $4(0.37)$ & $5(0.69)$ & $0.00 c$ \\
\hline Sigara kullanımı & $505(28.06)$ & $211(19.70)$ & $294(40.33)$ & 0.00 \\
\hline Sistemik hastallik varlığı & $527(29.28)$ & 363 (33.89) & $164(22.50)$ & 0.000 \\
\hline Tip 2 diyabet & $38(2.11)$ & $21(1.96)$ & $17(2.33)$ & 0.615 \\
\hline Hipertansiyon & $68(3.78)$ & $44(4.11)$ & $24(3.29)$ & $0.45 c$ \\
\hline Kardiyovasküler hastalık & $42(2.33)$ & $24(2.24)$ & $18(2.47)$ & 0.75 \\
\hline Tiroid hastalığı & $56(3.11)$ & $47(4.39)$ & $9(1.23)$ & 0.00 \\
\hline Alerji & $84(4.67)$ & $64(5.98)$ & $20(2.74)$ & 0.00 \\
\hline $\begin{array}{l}\text { Gastrointestinal sistem } \\
\text { hastalikları }\end{array}$ & $48(2.67)$ & $27(2.52)$ & $21(2.88)$ & 0.65 \\
\hline
\end{tabular}

Çalışmaya dahil edilen bireylerin \% 28.06'sının sigara kullandığı ve erkeklerde sigara tüketiminin daha fazla olduğu belirlendi $(p<0.001)$. Gingivitis grubunda kadın hastaların oranının daha fazla olduğu görülürken, KP grubunda erkek hastalar daha fazla idi $(p<0.001)$. Çalışma topluluğunun \% 29.28'inde sistemik hastalık ve/veya durumlardan en az birinin bulunduğu ve sistemik hastalık varlığının kadınlarda erkeklere göre daha yüksek oranda olduğu belirlendi. Tip 2 diyabet, hipertansiyon ve kardiyovasküler hastalıklar açısından kadın ve erkek bireyler arasında anlamlı bir farklılık görülmezken, tiroid hastalıkları ve alerjinin kadınlarda erkek bireylere göre anlamlı derecede daha yüksek oranda görüldüğü tespit edildi (sırasıyla $p<0.001$ ve $p=0.001)$.

Çalışmaya dahil edilen bireylerin periodontal teşhise göre dağılımı incelendiğinde \% 70.83'ünün $(n=1275) \mathrm{G}$, $\%$ 28.67'sinin ( $n=516)$ KP ve \% 0.50'sinin $(n=9)$ ise AgP olduğu tespit edildi (Tablo 2). Bu üç grup arasında en yüksek yaş ortalamasının KP grubunda olduğu görüldü (Tablo 3). Periodontal hastalık grupları sigara kullanımı açısından karşılaştırıldığında en yüksek sigara kullanım oranının KP grubunda olduğu belirlendi. Yine sistemik hastalıkların kronik periodontitisli hastalarda $\mathrm{G}$ ve $\mathrm{AgP}$ gruplarına göre daha yüksek oranda görüldüğü saptandı. Sistemik hastalıklar ayrı ayrı değerlendirildiğinde diyabet, hipertansiyon, kardiyovasküler hastalıklar ve tiroid hastalıklarının kronik periodontitisli hastalardaki oranının diğer gruplara göre daha yüksek olduğu tespit edildi (Tablo 4).

Tablo 3.

Çalışma popülasyonuna ait demografik verilerin ve klinik periodontal ölçümlerin periodontal teşhise göre karşılaştırılması

\begin{tabular}{|c|c|c|c|c|c|}
\hline & & G & KP & $\mathrm{AgP}$ & $\mathbf{P}^{*}$ \\
\hline \multirow{2}{*}{ Yaş } & ort $\pm s s$ & $25.03 \pm 8.22$ & $40.45 \pm 12.06^{\mathrm{a}}$ & $30.78 \pm 6.28^{\mathrm{a}, \mathrm{b}}$ & \multirow{2}{*}{0.000} \\
\hline & $\begin{array}{l}\text { ortanca (min- } \\
\text { maks) }\end{array}$ & $\begin{array}{l}22.00(12.00- \\
70.00)\end{array}$ & $\begin{array}{l}39.00 \text { (16.00- } \\
76.00)\end{array}$ & $\begin{array}{l}31.00(19.00- \\
38.00)\end{array}$ & \\
\hline \multirow{2}{*}{$\mathrm{Pi}$} & ort $\pm s s$ & $1.31 \pm 0.48$ & $1.49 \pm 0.55^{\mathrm{a}}$ & $1.52 \pm 0.65$ & \multirow{2}{*}{0.000} \\
\hline & $\begin{array}{l}\text { ortanca (min- } \\
\text { maks) }\end{array}$ & $1.13(0.00-3.00)$ & $1.38(0.00-3.00)$ & $1.63(0.71-2.76)$ & \\
\hline \multirow{2}{*}{ Gi } & ort $\pm s s$ & $1.33 \pm 0.48$ & $1.61 \pm 0.53^{\mathrm{a}}$ & $1.64 \pm 0.68$ & \multirow{2}{*}{0.000} \\
\hline & $\begin{array}{l}\text { ortanca (min- } \\
\text { maks) }\end{array}$ & $1.13(0.00-3.00)$ & $1.69(0.00-3.00)$ & $1.50(0.86-3.00)$ & \\
\hline \multirow{2}{*}{$\mathrm{SK}_{\%}$} & ort $\pm s s$ & $41.25 \pm 39.33$ & $63.14 \pm 38.33^{\mathrm{a}}$ & $84.94 \pm 21.07^{\mathrm{a}}$ & \multirow{2}{*}{0.000} \\
\hline & $\begin{array}{l}\text { ortanca (min- } \\
\text { maks) }\end{array}$ & $\begin{array}{l}31.25(0.00- \\
100.00)\end{array}$ & $\begin{array}{l}75.00(0.00- \\
100.00)\end{array}$ & $\begin{array}{l}100.00(43.75- \\
100.00)\end{array}$ & \\
\hline
\end{tabular}

* Kruskal Wallis - Mann Whitney U test, $p<0.05$

${ }^{a} G$ grubuna göre farkllık, ${ }^{b} K P$ grubuna göre farklılık

PI: plak indeksi, Gi: gingival indeks, SK: sondlamada kanama, G: gingivitis, KP: kronik periodontitis, AgP: agresif periodontitis, ort \pm ss: aritmetik ortalama \pm standart sapma, min minimum, maks: maksimum

Tablo 4.

Çalışma popülasyonuna ait sigara kullanımı ve sistemik hastalık verilerinin periodontal teşhise göre karşılaştırılması

\begin{tabular}{|ll|lll|}
\hline Sigara kullanımı & \multicolumn{1}{c|}{$\begin{array}{c}\mathbf{G} \\
\mathbf{n}(\%)\end{array}$} & $\begin{array}{c}\text { KP } \\
\mathbf{n}(\%)\end{array}$ & $\begin{array}{c}\text { AgP } \\
\mathbf{n}(\%)\end{array}$ & $\mathbf{P}^{*}$ \\
\hline Sistemik hastalık varlığı & $320(25.10)$ & $182(35.27)$ & $3(33.33)$ & 0.000 \\
\hline Tip 2 diyabet & $337(26.43)$ & $188(36.43)$ & $2(22.22)$ & 0.000 \\
\hline Hipertansiyon & $10(0.78)$ & $28(5.43)$ & 0 & 0.000 \\
\hline Kardiyovasküler hastallık & $24(1.88)$ & $44(8.53)$ & 0 & 0.000 \\
\hline Tiroid hastalığı & $19(1.49)$ & $23(4.46)$ & 0 & 0.001 \\
\hline Alerji & $30(2.35)$ & $26(5.04)$ & 0 & 0.011 \\
\hline Gastrointestinal sistem hastalıkları & $61(4.94)$ & $23(4.07)$ & 0 & 0.586 \\
\hline
\end{tabular}

\# Ki-kare test, $p<0.05$

G: gingivitis, KP: kronik periodontitis, AgP: agresif periodontitis, $n$ : birey sayıs 
Periodontitis gelişiminde rol oynayan olası risk göstergelerine ait odds oranı (OO) ve güven aralığı (GA) değerleri Tablo 5'de verildi.

Tablo 5.

\section{Periodontitis gelişiminde rol oynayan hasta ile ilişkili olası risk göstergeleri}

\begin{tabular}{|c|c|c|c|c|}
\hline \multicolumn{5}{|c|}{ Periodontitis } \\
\hline \multicolumn{5}{|c|}{ Çok değişkenli regresyon } \\
\hline Değişken & & oo & $95 \%$ GA & $\mathrm{p}$ \\
\hline Yaş & & 1162 & $(1.144-1.180)$ & $0.000^{*}$ \\
\hline Piort & & 1335 & $(1.015-1.756)$ & $0.039^{*}$ \\
\hline SK\% & & 1014 & $(1.011-1.018)$ & $0.000^{*}$ \\
\hline Cinsiyet & Erkek & 1385 & $(1.046-1.834)$ & $0.023^{*}$ \\
\hline Sigara kullanımı & Evet & 1507 & $(1.128-2.013)$ & $0.006^{*}$ \\
\hline Sistemik hastalık & Evet & 0.684 & $(0.480-0.974)$ & $0.035^{*}$ \\
\hline Tip 2 diyabet & Evet & 1588 & $(0.569-4.427)$ & 0.377 \\
\hline Hipertansiyon & Evet & 0.339 & $(0.159-0.725)$ & $0.005^{*}$ \\
\hline Kardiyovasküler hastalık & Evet & 0.543 & $(0.210-1.401)$ & 0.207 \\
\hline Tiroid hastalıkları & Evet & 1050 & $(0.502-2.193)$ & 0.897 \\
\hline Gastrointestinal sistem hastallkları & Evet & 1291 & $(0.562-2.968)$ & 0.547 \\
\hline
\end{tabular}

Çok kategorili (multinominal) lojistik regresyon modeline göre; yaş $(O O=1.162$, \% 95 GA 1.1441.180), Pi $(\mathrm{OO}=1.335, \% 95 \mathrm{GA} 1.015-1.756)$, SK $(O O=1.014, \% 95$ GA 1.011-1.018), sigara kullanımı $(O O=1.507, \% 95 \mathrm{GA} 1.128-2.013)$, sistemik hastalık varlığı $(O O=0.684, \% \quad 95 \quad G A \quad 0.480-0.974)$ ve hipertansiyon $(\mathrm{OO}=0.339$, \% 95 GA $0.159-0.725)$ değişkenlerinin periodontitis gelişme ihtimalini arttırdığı tespit edildi.

\section{TARTIŞMA}

$\mathrm{Bu}$ kesitsel retrospektif çalışmada, Bolu Abant İzzet Baysal Üniversitesi Diş Hekimliği Fakültesi Periodontoloji Anabilim Dalı öğrenci kliniğine başvuran 1800 hastanın periodontal durum, kişisel alışkanlık ve sistemik hastalıklarının değerlendirilmesi amaçlandı.

Küresel bir halk sağlığı sorunu olan periodontal hastalıkların toplumda görülme sıklığı incelenen topluluğun biyolojik ve ekolojik özelliklerindeki farklılıklara bağlı olarak değişiklik gösterebilmektedir. Çalışmamızda kliniğe başvuran bireylerin \% 70.83'ünün gingivitis, \% 28.67'sinin kronik periodontitis ve \% 0.50'sinin ise agresif periodontitis hastası olduğu tespit edildi. Literatürde bu araştırmanın sonuçlarına benzer şekilde çalışma popülasyonunda gingivitis oranının periodontitis oranından daha fazla olduğunu bildiren yayınlar olmakla birlikte ${ }^{10,13,17}$, periodontitis oranının daha yüksek bulunduğu çalışmalar da mevcuttur. ${ }^{11,12}$

Periodontal durum ve cinsiyet arasındaki ilişkiyi inceleyen çalışmaların çoğunda erkeklerde periodontal hastalık prevalansı ve şiddetinin daha yüksek olduğu gösterilmiştir. ${ }^{18,19}$ Cinsiyetler arasındaki bu farklılığın genetik faktörlerden ziyade ağız bakımı alışkanlıkları ile ilişkili olduğuna inanılmaktadır. Bu çalışmada ise gingivitis görülme oranının kadınlarda erkeklerden daha fazla olduğu, periodontitis görülme oranının ise erkeklerde kadınlara göre daha yüksek olduğu tespit edildi. Bu sonucun erkek bireylerde sigara kullanım oranının daha yüksek olması ve yetersiz ağız bakımı (yüksek Pi, Gi ve SK değerleri) ile ilişkili olabileceği düşünülmektedir.

Mevcut epidemiyolojik kanıtlar periodontal yıkım görülme sıklığının ve şiddetinin yaşla birlikte arttığını göstermektedir. ${ }^{20-22}$ Güncel çalışmalarda şiddetli periodontitis prevalansının yaşamın üçüncü ve dördüncü dekatları arasında yüksek bir artış gösterebileceği ve daha ileri yaşlarda bu prevalansın nispeten sabit kalabileceği belirtilmiştir. ${ }^{23}$ Yaşlanmanın periodontitis üzerindeki etkisi biyolojik değişimlerden ziyade risk faktörlerine maruziyetin kümülatif olarak artışına atfedilmiştir. ${ }^{24}$ Literatürle uyumlu olarak bu çalışmada periodontitisli bireylerin yaş ortalaması gingivitisli bireylerden yüksek bulundu ve yaş artışının periodontitis olma intimalini arttırdığı saptandı. Sigara kullanımı periodontal hastalık gelişiminde en önemli risk faktörlerinden biridir. ${ }^{25-27}$ Sigaranın bazı periodontal patojenlerin sayısında artışa neden olduğu, oral mikrobiyal florayı değiştirdiği ve konak yanıtını etkilediği bildirilmiştir. ${ }^{28}$ Ayrıca nikotinin doğrudan ya da diğer faktörlerle etkileşim yoluyla dolaylı olarak periodontal doku yıkımına neden olduğu gösterilmiştir. ${ }^{29}$ Yapılan çalışmalarda sigara iç̧en bireylerde periodontal hastalık gö̈ulme oranının sigara içmeyen bireylere göre daha yuiksek oldugu, sigaranın periodontal dokulardaki yıkımı şiddetini arttırdığı ve periodontal tedavinin etkinliğini olumsuz yönde etkilediği kanıtlanmıştır. ${ }^{26,30-34}$ Bizim çalışmamızda da KP grubunda sigara içme oranının gingivitis grubundan daha fazla olduğu ve sigara kullanımının periodontitis gelişme olasılığını arttırdığı tespit edildi.

Periodontal hastalıklar ile birçok sistemik hastalık ortak risk faktörlerine sahip olup patofizyolojilerinin de benzer olabileceği bildirilmiştir.5,7,9 Bu nedenle bu hastalıklardan birinin varlığı diğer hastalıkların ortaya çıkma ihtimalini arttırmaktadır. Csalıșmamızda periodontal hastalıklı bireylerin \% 29.28'inde en az bir sistemik hastalık olduğu saptandı. Literatürdeki çalışmalara benzer şekilde ${ }^{10-13}$, en yüksek sistemik hastalık görülme oranının kronik periodontitis hastalarında olduğu görüldü. Ayrıca sistemik hastalık varlığının periodontitis görülme ihtimali arttırdığı tespit edildi.

Ağız sağlığı ile kronik sistemik hastalıklar arasındaki etkileşim incelendiğinde, periodontal hastalık ve tip 2 diyabet arasındaki çift yönlü ilişki öne çıkmaktadır. ${ }^{35-37}$ Diyabetli kişilerde periodontal hastalık riskinin daha yüksek olduğu bildirilmiş ve periodontal hastalıklar diyabetin altıncı komplikasyonu olarak kabul edilmiştir. ${ }^{38-40}$ Yapılan çalışmalarda diyabetli kişilerde 
diyabetli olmayanlara göre daha derin periodontal cepler, daha şiddetli alveolar kemik kaybı ve daha sık abse formasyonu görüldüğü ve periodontal tedavi sonrası iyileşmenin daha zayıf olduğu bildirilmiştir. ${ }^{41-45}$ Diğer yandan periodontal hastalıklı bireylerin periodontal açıdan sağlıklı diyabet hastalarından daha zayıf glisemik kontrole sahip olabilecekleri gösterilmiştir. ${ }^{35} \mathrm{Bu}$ bulgularla uyumlu olarak bu çalışmada periodontitis grubunda diyabet görülme oranının gingivitis grubuna göre daha yüksek olduğu, diğer taraftan, diyabet varlığının periodontitis gelişiminde önemli olmadığı belirlendi.

Periodontal hastalık ve hipertansiyonun ortak risk faktörlerine (yaş, cinsiyet, genetik yatkınlık, sigara, kötü beslenme alışkanlıkları, diyabet, sosyo-ekonomik durum vs.) sahip olduğu bilinmektedir. Bunun yanında periodontal hastalığın endotelyal ve vasküler disfonksiyona neden olarak kan basıncında artışa yol açabileceği bildirilmiştir. Araştırmacılar periodontitisli bireylerde periodontitis olmayan bireylere göre sistolik ve diyastolik kan basınçların daha yüksek olduğunu gözlemlemişlerdir. ${ }^{46,47}$ Ayrıca orta yaşlı bireylerde sistolik kan basıncı ile şiddetli periodontitis arasında pozitif yönlü doğrusal ilişki olduğu bulunmuştur. ${ }^{47} \mathrm{Bu}$ verileri destekler nitelikte bizim çalışmamızda kronik periodontitisli bireylerde hipertansiyon görülme oranının daha yüksek olduğu ve hipertansiyonun periodontitis görülme ihtimalini arttırdığı tespit edildi.

Literatürde periodontal hastalık varlığı kardiyovasküler hastalıklar için, kardiyovasküler bozukluklar da periodontal hastalık gelişimi için önemli bir risk faktörü olarak tanımlanmıştır. ${ }^{48}$ Periodontal hastalık varlığında proinflamatuar sitokinlerin üretilmesi ve epitelde hasar meydana gelmesi, endotoksinlerin ve ekzotoksinlerin kan dolaşımına girmesine izin verir. $\mathrm{Bu}$ durum aterojenez ve tromboembolik durumların gelişimine katkıda bulunabilir. Bunun yanında oral patojenlerin damar duvarına doğrudan invazyonu inflamatuar yanıtı tetikleyerek endotelyal disfonksiyonuna neden olabilir. Diğer yandan hipertansiyon durumunda mikrodolaşımdaki değişiklikler periodonsiyumda iskemiye neden olabilir ve bu da periodontal hastalığı destekler. ${ }^{48}$ Periodontitis ile kardiyovasküler hastalık varlığı arasındaki ilişkiyi gösteren çalışmalara benzer şekilde ${ }^{10,11,13,49}$ bu çalışmada kardiyovasküler hastalık görülme olasılığının periodontitis varlığında daha fazla olduğu saptandı.

Endokrin sistemin periodontal dokuların da içinde bulunduğu oral kavite ve iskeletsel yapıların gelişiminde ve bütünlüğünün korunmasında önemli etkileri olduğu bilinmektedir. ${ }^{50-52}$ Puberte, menstrual siklus, hamilelik veya menopoz dönemlerinde görülen hormonal değişimlerin dişeti epiteli, bağ dokusu, mikrovasküler yapılar, kemik mineral yoğunluğu ve konak inflamatuar yanıtı üzerindeki etkileri periodontal hastalık gelişimine ve şiddetli doku yıkımına katkıda bulunabilir. ${ }^{53-59}$ Tiroid hastalıkları da yaygın olarak görülen endokrin sistem hastalıklarındandır. Tiroid fonksiyon bozukluğu sonucu gelişen hipotiroidi, hipertiroidi ve guatr en sık karşılaşılan tiroid hastalıklarıdır ve kadınlarda görülme oranları daha fazladır. ${ }^{60}$ Literatürde tiroid fonksiyon bozukluğu olan bireylerin diş çürüğü ve periodontal hastalık gelişimine daha yatkın olduğu belgelenmiştir. ${ }^{61}$ Ayrıca kemik kaybı, kök rezorpsiyonu ve periodontal kaynaklı diş kaybı gibi durumların tiroid fonksiyon bozukluğuna eşlik edebileceği gösterilmiştir. Tiroid fonksiyon bozukluğu olan hastalarda periodontal hastalık insidansındaki ve şiddetindeki artışın nedeni hala tam olarak bilinmemekle birlikte, tiroid hormonlarının serum seviyesindeki azalmanın rezorbe edici hücre sayısındaki artışa neden olarak periodontitise bağlı kemik kaybındaki artış ile ilişkili olabileceği düşünülmektedir. ${ }^{62}$ Hastalık sürecinin kendisinin veya tedavisinin (cerrahi tedavinin veya alınan ilaçların) de ağız sağlığındaki olumsuz etkilerden sorumlu olabileceği bildirilmiştir. Bu verilerle uyumlu olarak bizim çalışmamızda da kadın popülasyonunda erkeklere göre ve kronik periodontitis grubunda diğer gruplara göre daha fazla tiroid hastası olduğu tespitedildi.

Ağız boşluğu gastrointestinal sistemin başlangıç bölümünü oluşturmaktadır. $\mathrm{Bu}$ nedenle gastrointestinal sistemi etkileyen patolojik süreçler ağız boşluğunda değişikliklere neden olabilir. Literatürde periodontal durumun gastrointestinal sistem hastalıkları (gastroözefagal reflü, ülseratif kolit, gastrit) ile ilişkili olduğu bildirilmiştir. ${ }^{63,64}$ Gastrointestinal hastalıklara neden olan en önemli bakterilerden biri olan Helicobacter pylori (H. pylori)'nin tükürük, dil dorsumu ve dental plakta rezervuar olarak bulunabildiği65 ve oral $\mathrm{H}$. pylori'nin kronik periodontitis için olası bir risk faktörü olduğu belirtilmiştir. ${ }^{66}$ Bir metaanalizde, periodontal hastalığı olan hastalarda oral $\mathrm{H}$. pylori insidansının, kontrol grubuna göre anlamlı derecede (3.42 kez) arttığı ve oral H. pylori oranının kronik periodontitis insidansı ile ilişkili olduğu bulunmuştur. ${ }^{67}$ Ayrıca periodontal hastalık varlığında mide ve duodenum ülseri riskinin arttığı bildirilmiştir ${ }^{64}$ Inflamatuar bağırsak hastalığı bulunan bireylerde, özellikle Crohn hastalığı olanlarda, olmayan bireylere göre periodontitis riskinin arttığı gösterilmiştir. ${ }^{68-70}$ Diğer yandan mide ve oral $\mathrm{H}$. pylori varlığı ile dişeti kanaması, sondlama derinliği ve ataçman kaybı arasında anlamlı bir ilişki bulunmadığını ${ }^{71}$, kontrol grubu ile kronik periodontitis grubu arasında $H$. pylori pozitifliği açısından anlamlı farklılık olmadığını gösteren çalışmalar da mevcuttur. ${ }^{72}$ Bizim çalışmamızda ise gastrointestinal sistem hastalığı görülme sıklığı açısından çalışma grupları arasında anlamlı fark bulunmadığı tespit edildi.

Periodontal hastalık, hem ekonomik hem sosyal açıdan önemli etkileri olan büyük bir halk sağlığı sorunudur. Periodontal hastalıklar gibi toplumun geniş 
bir kesimini etkileyen hastalıklara ait verilerin toplanması bir yandan mevcut durumun tespit edilmesine ve kontrol altında tutulmasına olanak sağlarken, bir yandan da ileriye dönük olarak bireylerin hastalıktan korunmasına ve hastalığa bağlı gelişen olumsuz sonuçların önlenmesine yönelik stratejilerin planlanmasında ihtiyaç duyulan bilgiyi sağlar. ${ }^{73}$ Diğer yandan hastaların uzun süre belirti vermeden ilerleyebilen ve çoğunlukla gözardı edilen lokal bir hastalığın, birçok kronik hastalığın gelişimine katkıda bulunabileceğini bilmesi ve mevcut periodontal hastalığının tedavisinin diğer kronik hastalıklara yakalanma riskini azaltabileceğinin bilincine varması, ağız bakımlarına özen göstermelerine ve düzenli olarak diş hekimi kontrolüne gitmelerine katkıda bulunabilir. Böylece hem periodontal hastalık hem de ilişkili diğer kronik hastalıkların görülme sıklığının ve şiddetinin azaltılabileceği düşünülmektedir.

Çalışma popülasyonunun sadece periodontoloji kliniğine başvuran hastalardan oluşması ve çalışmada periodontal olarak sağlıklı bireylerin bulunmaması çalışmamızın limitasyonları olarak kabul edilebilir. Ayrıca sistemik hastalık verileri hastaların kendi beyanlarına dayanarak değerlendirildiğinden ve mevcut hastalığının farkında olmayan bireyler de çalışmada yer almış olabileceğinden eksik veriler olabilir. Menapoz döneminde bulunan bireylerin de çalışmaya dahil edilmiş olması, bu dönemde görülen hormonal değişimlerin periodontal enflamasyon şiddeti ve doku hasarında rolü olabilmesi nedeni ile çalışmanın sonuçlarını etkilemiş olabilir. Periodontal klinik ölçümlerin farklı kişiler tarafından yapılmış olması da bir limitasyon olarak düşünülebilir ancak, hastaların son teşhislerin tek bir kişi tarafından yapılmış olması önemlidir. Çalışmamızda incelenen verilerin 2014-2016 yılları arasına ait olması nedeniyle periodontal teşhis kriterleri 1999 yılında yapılan periodontal hastalık sınıflamasına göre belirlenmiştir. Daha sonraki çalışmalarda periodontal durumun belirlenmesinde 2017 yilında geliştirilen ve evre-derece sistemine dayanan yeni sınıflandırmanın kullanılmasının mevcut durumun saptanmasında ve periodontal hastalık prognozunun öngörülmesinde daha yararlı olacağı düşünülmektedir.

\section{SONUÇ}

Bu çalışmanın sınırları dahilinde, sistemik durum ve kişisel alışkanlıkların periodontal hastalık gelişiminde ve şiddetinde önemli rol oynayabileceği sonucu çıkarılabilir. Periodontal durum ve sistemik hastalıklar arasındaki çift yönlü ilişki düşünüldüğünde, hastaların hem periodontal hastalıklarının tedavisi hem de sistemik durumlarının kontrol altında tutulması gerektiği konusunda bilgilendirilmelerinin ve motive edilmelerinin önemli olduğu düşünülmektedir. 


\section{KAYNAKLAR}

1. Bratthall D, Petersen PE, Stjernsward JR, Brown LJ. Oral and Craniofacial Diseases and Disorders (Chapter 38). In: Jamison DT, Breman JG, Measham AR, Alleyne G, Claeson M, et al., editors. Disease Control Priorities in Developing Countries. New York: World Bank Health and Oxford University Press, 2006: 723-736.

2. Loe H, Theilade E, Jensen SB. Experimental Gingivitis in Man. J Periodontol. 1965;36:177-87.

3. Loesche WJ, Grossman NS. Periodontal disease as a specific, albeit chronic, infection: diagnosis and treatment. Clin Microbiol Rev. 2001;14(4):727-52.

4. Socransky SS, Haffajee AD. The Bacterial Etiology of Destructive Periodontal Disease: Current Concepts. J Periodontol. 1992;63 Suppl 4S:322-31.

5. Scannapieco FA. Systemic effects of periodontal diseases. Dent Clin North Am. 2005;49(3):533-50.

6. Cullinan MP, Ford PJ, Seymour GJ. Periodontal disease and systemic health: current status. Aust Dent J. 2009;54 Suppl 1:S62-9.

7. Scannapieco FA, Dasanayake AP, Chhun N. "Does periodontal therapy reduce the risk for systemic diseases?". Dent Clin North Am. 2010;54(1):163-81.

8. Manjunath BC, Praveen K, Chandrashekar BR, Rani RM, Bhalla A. Periodontal infections: a risk factor for various systemic diseases. Natl Med $\mathrm{J}$ India. $2011 ; 24(4): 214-9$.

9. Cullinan MP, Seymour GJ. Periodontal disease and systemic illness: will the evidence ever be enough? Periodontol 2000. 2013;62(1):271-86.

10.Akpınar $A$, Toker $H$, Çalışır $M$. Periodontoloji kliniğne bassvuran hastalarda periodontal durum ve sistemik hastalıkların degerlendirilmesi. Cumhuriyet Dent J. 2012;15(2):93-100.

11.Demir Kodalak S, Öztürk Özener H, Ağralı ÖB, Yıldırım HS, Kuru L. Periodontoloji anabilim dalı öğrenci kliniğinde 2012-2014 yıllarında tedavi edilen hastaların periodontal ve sistemik durumları. Yeditepe J Dent. 2018;14(1):55-62.

12. Çalışır M, Talmaç AC. Dişhekimliğ fakuiltesine bașvuran hastalarda periodontal durum ve sistemik hastalıkların değerlendirilmesi. AU Sağlık Bil Derg. 2018;4(2):73849.

13. Sezgin Y, Nişancı Yılmaz MN. Periodontoloji kliniğine başvuran hastaların periodontal durumlarının ve sistemik hastalıklarının değerlendirilmesi. J Dent Fac Atatürk Uni. 2019;29(3):432-9.

14. Silness J, Loe H. Periodontal Disease in Pregnancy. li. Correlation between Oral Hygiene and Periodontal Condtion. Acta Odontol Scand. 1964;22:121-35.

15. Loe H. The Gingival Index, the Plaque Index and the Retention Index Systems. J Periodontol. 1967;38(6):Suppl:610-6.

16. Armitage GC. Development of a classification system for periodontal diseases and conditions. Ann Periodontol. 1999;4(1):1-6.

17.Eren G, Becerik S. Evaluating the periodontal status and oral hygiene habits among dental patients. İstanbul Med J. 2016(17):93-8.
18. Madden IM, Stock CA, Holt RD, Bidinger PD, Newman HN. Oral health status and access to care in a rural area of India. J Int Acad Periodontol. 2000;2(4):110-4.

19.Brown LF, Beck JD, Rozier RG. Incidence of attachment loss in community-dwelling older adults. J Periodontol. 1994;65(4):316-23.

20.Baelum V, Luan WM, Chen X, Fejerskov O. A 10year study of the progression of destructive periodontal disease in adult and elderly Chinese. J Periodontol. 1997;68(11):1033-42.

21.Baelum V, Luan WM, Chen X, Fejerskov O. Predictors of destructive periodontal disease incidence and progression in adult and elderly Chinese. Community Dent Oral Epidemiol. 1997;25(4):265-72.

22. Beck JD, Sharp T, Koch GG, Offenbacher S. A 5year study of attachment loss and tooth loss in community-dwelling older adults. J Periodontal Res. 1997;32(6):516-23.

23. Kassebaum NJ, Bernabe E, Dahiya M, Bhandari B, Murray CJ, Marcenes W. Global burden of severe periodontitis in 1990-2010: a systematic review and meta-regression. J Dent Res. 2014;93(11):1045-53.

24. Hajishengallis $\mathrm{G}$. Too old to fight? Aging and its toll on innate immunity. Mol Oral Microbiol. 2010;25(1):25-37.

25. Molloy J, Wolff LF, Lopez-Guzman A, Hodges JS. The association of periodontal disease parameters with systemic medical conditions and tobacco use. J Clin Periodontol. 2004;31(8):625-32.

26. Nociti FH, Jr., Casati MZ, Duarte PM. Current perspective of the impact of smoking on the progression and treatment of periodontitis. Periodontol 2000. 2015;67(1):187-210.

27. Salvi GE, Lawrence HP, Offenbacher S, Beck JD. Influence of risk factors on the pathogenesis of periodontitis. Periodontol 2000. 1997;14:173-201.

28.Bergstrom J. Smoking rate and periodontal disease prevalence: 40-year trends in Sweden 1970-2010. J Clin Periodontol. 2014;41(10):952-7.

29. Nociti FH, Jr., Nogueira-Filho GR, Tramontina VA, Machado MA, Barros SP, Sallum EA, et al. Histometric evaluation of the effect of nicotine administration on periodontal breakdown: an in vivo study. J Periodontal Res. 2001;36(6):361-6.

30. Haffajee AD, Socransky SS. Relationship of cigarette smoking to attachment level profiles. J Clin Periodontol. 2001;28(4):283-95.

31.Bergstrom J. Influence of tobacco smoking on periodontal bone height. Long-term observations and a hypothesis. J Clin Periodontol. 2004;31(4):260-6.

32. Grossi SG, Skrepcinski FB, DeCaro T, Zambon JJ, Cummins D, Genco RJ. Response to Periodontal Therapy in Diabetics and Smokers. J Periodontol. 1996;67 Suppl 10S:1094-102. 
33. Tomar SL, Asma S. Smoking-attributable periodontitis in the United States: findings from NHANES III. National Health and Nutrition Examination Survey. J Periodontol. 2000;71(5):743-51.

34. Leite FRM, Nascimento GG, Scheutz F, Lopez R. Effect of Smoking on Periodontitis: A Systematic Review and Meta-regression. Am J Prev Med. 2018;54(6):831-41.

35. Grossi SG, Genco RJ. Periodontal disease and diabetes mellitus: a two-way relationship. Ann Periodontol. 1998;3(1):51-61.

36. Mealey BL, Oates TW, American Academy of $P$. Diabetes mellitus and periodontal diseases. J Periodontol. 2006;77(8):1289-303.

37.Soskolne WA, Klinger A. The relationship between periodontal diseases and diabetes: an overview. Ann Periodontol. 2001;6(1):91-8.

38. Taylor GW. Bidirectional interrelationships between diabetes and periodontal diseases: an epidemiologic perspective. Ann Periodontol. 2001;6(1):99-112.

39. lacopino AM. Periodontitis and diabetes interrelationships: role of inflammation. Ann Periodontol. 2001;6(1):125-37.

40. Oliver RC, Tervonen T. Diabetes-A Risk Factor for Periodontitis in Adults? J Periodontol. 1994;65 Suppl 5S:530-8.

41.Taylor GW, Borgnakke WS. Periodontal disease: associations with diabetes, glycemic control and complications. Oral Dis. 2008;14(3):191-203.

42. Borges-Yanez SA, Irigoyen-Camacho ME, Maupome G. Risk factors and prevalence of periodontitis in community-dwelling elders in Mexico. $J$ Clin Periodontol. 2006;33(3):184-94.

43. Emrich LJ, Shlossman M, Genco RJ. Periodontal disease in non-insulin-dependent diabetes mellitus. J Periodontol. 1991;62(2):123-31.

44.Khader YS, Dauod AS, El-Qaderi SS, Alkafajei A, Batayha WQ. Periodontal status of diabetics compared with nondiabetics: a meta-analysis. J Diabetes Complications. 2006;20(1):59-68.

45.Soskolne WA. Epidemiological and clinical aspects of periodontal diseases in diabetics. Ann Periodontol. 1998;3(1):3-12.

46. Desvarieux M, Demmer RT, Jacobs DR, Jr., Rundek T, Boden-Albala B, Sacco RL, et al. Periodontal bacteria and hypertension: the oral infections and vascular disease epidemiology study (INVEST). J Hypertens. 2010;28(7):1413-21.

47.Tsakos G, Sabbah W, Hingorani AD, Netuveli G, Donos $\mathrm{N}$, Watt $\mathrm{RG}$, et al. Is periodontal inflammation associated with raised blood pressure? Evidence from a National US survey. J Hypertens. 2010;28(12):2386-93.

48. Macedo Paizan ML, Vilela-Martin JF. Is there an association between periodontitis and hypertension? Curr Cardiol Rev. 2014;10(4):355-61.

49. Emingil G. Periodontoloji Kliniğine Başvuran Hastalarda Sistemik Hastalıkların Görulme Sıklıkları. EÜ Dişhek Fak Derg. 2001;22:59-62.

50. Mariotti A. Sex steroid hormones and cell dynamics in the periodontium. Crit Rev Oral Biol Med. 1994;5:27-53.
51. Mealey L, Moritz J. Hormonal influences on periodontium. Periodontol 2000. 2003;32:59-81.

52.Lorenzo J. A new hypothesis for how sex steroid hormones regulate bone mass. J Clin Invest. 2003;111:1641-1643.

53.López-Marcos JF, García-Valle S, and GarcíaIglesias AA. Periodontal aspects in menopausal women undergoing hormone replacement therapy. Med Oral Patol Oral Cir Bucal. 2005;10(2):132-141.

54.Shu L, Guan S-M, Fu S-M, Guo T, Cao M, Ding Y. Estrogen modulates cytokine expression in human periodontal ligament cells. J Dent Res. 2008;87(2):142-7.

55.Grover CM, More VP, Singh N, Grover S. Crosstalk between hormones and oral health in the mid-life of women: A comprehensive review. J Int Soc Prev Community Dent. 2014;4:S5-10.

56. Lerner UH. Bone remodeling in post-menopausal osteoporosis. J Dent Res. 2006;85:584-95.

57.Wactawski-Wende J. Periodontal diseases and osteoporosis: association and mechanisms. Ann Periodontol. 2001;6:197- 208.

58. Friedlander $\mathrm{AH}$. The physiology, medical management and oral implications of menopause. J Am Dent Assoc. 2002;133:73-81.

59. Mascarenhas P, Gapski R, Al-Shammari K, Wang $\mathrm{H}-\mathrm{L}$. Influence of sex hormones on the periodontium. J Clin Periodontol. 2003;30:671681

60.Larsen PR, Davies TF, Hay ID. The Thyroid. In: Williams RH, Wilson JD, Foster DW, Kronenberg HM, editors. Williams Textbook of Endocrinology. 9th ed. Philadelphia: Saunders, 1998: 389-416.

61.Pinto A, Glick M. Management of patients with thyroid disease: oral health considerations. J Am Dent Assoc. 2002;133(7):849-58.

62.Feitosa DS, Marques MR, Casati MZ, Sallum EA, Nociti FH, Jr., de Toledo S. The influence of thyroid hormones on periodontitis-related bone loss and tooth-supporting alveolar bone: a histological study in rats. J Periodontal Res. 2009;44(4):472-8.

63. Vinesh $E$, Masthan K, Kumar MS, Jeyapriya SM, Babu A, Thinakaran M. A Clinicopathologic Study of Oral Changes in Gastroesophageal Reflux Disease, Gastritis, and Ulcerative Colitis. J Contemp Dent Pract. 2016;17(11):943-7.

64.Boylan MR, Khalili H, Huang ES, Michaud DS, Izard J, Joshipura KJ, et al. A prospective study of periodontal disease and risk of gastric and duodenal ulcer in male health professionals. Clin Transl Gastroenterol. 2014;5:e49.

65. Kobayashi T, Murasawa A, Komatsu Y, Yokoyama T, Ishida K, Abe A, et al. Serum cytokine and periodontal profiles in relation to disease activity of rheumatoid arthritis in Japanese adults. J Periodontol. 2010;81(5):650-7. 
66. Adler I, Muino A, Aguas S, Harada L, Diaz M, Lence A, et al. Helicobacter pylori and oral pathology: relationship with the gastric infection. World J Gastroenterol. 2014;20(29):9922-35.

67. Wei X, Zhao HQ, Ma C, Zhang AB, Feng $H$, Zhang D, et al. The association between chronic periodontitis and oral Helicobacter pylori: A meta-analysis. PLoS One. 2019;14(12):e0225247.

68. Yu HC, Chen TP, Chang YC. Inflammatory bowel disease as a risk factor for periodontitis under Taiwanese National Health Insurance Research database. J Dent Sci. 2018;13(3):242-7.

69. Flemmig TF, Shanahan F, Miyasaki KT. Prevalence and severity of periodontal disease in patients with inflammatory bowel disease. J Clin Periodontol. 1991;18(9):690-7.

70.Brito F, Zaltman C, Carvalho AT, Fischer RG, Persson $R$, Gustafsson A, et al. Subgingival microflora in inflammatory bowel disease patients with untreated periodontitis. Eur J Gastroenterol Hepatol. 2013;25(2):239-45.

71.Alagl AS, Abdelsalam M, El Tantawi M, Madi M, Aljindan $\mathrm{R}$, Alsayyah A, et al. Association between Helicobacter pylori gastritis and dental diseases: A cross-sectional, hospital-based study in Eastern Saudi Arabia. J Periodontol. 2019;90(4):375-80.

72. Salehi MR, Shah Aboei M, Naghsh N, Hajisadeghi S, Ajami E. A Comparison in Prevalence of Helicobacter pylori in the Gingival Crevicular Fluid from Subjects with Periodontitis and Healthy Individuals using Polymerase Chain Reaction. J Dent Res Dent Clin Dent Prospects. 2013;7(4):238-43.

73.Petersen PE, Ogawa $\mathrm{H}$. The global burden of periodontal disease: towards integration with chronic disease prevention and control. Periodontol 2000. 2012;60(1):15-39.

Yazışma Adresi:

Bilge MERACI YILDIRAN

Karabük Üniversitesi Diş Hekimliği Fakültesi

Periodontoloji AD.

Karabük, Türkiye

E Posta: bilgemrc@gmail.com 